\title{
THE ANALYSIS OF BRAINSTORMING STRATEGY ON TEACHING WRITING IN THE UNIVERSITY LEVEL
}

\author{
Elia Puspitasari \\ STKIP PGRI Tulungagung \\ elialovers17@gmail.com
}

Titik Lina Widyaningsih

STKIP PGRI Tulungagung

titiklina@gmail.com

\begin{abstract}
This research was aimed to analyze a brainstorming strategy on teaching writing, especially in writing a short story for the second-semester students of the English Department in (STKIP) PGRI Tulungagung in the academic year 2017/2018. This research was conducted using qualitative methodology. The researcher observed and analyzed the writing class where the lecturer was applying a brainstorming strategy. Qualitative data had been collected from observation of the teaching-learning process, interview with the lecturer and the students, and also questionnaire given to twenty students in that class. The data was in the form of observation, interview transcripts, and the results of the questionnaire. In this research, the researcher involved twenty participants to fill the questionnaire. There were six students from those twenty students and the lecturer who were involved in the process of interview. The result of the research showed that implementing a brainstorming strategy in writing class could improve student's skills in writing, especially writing a short story. The brainstorming strategy helped students to generate their ideas and express the ideas into a systematic paragraph. The students also felt that this strategy could improve their writing. When the lecturer applied a brainstorming strategy, the students could do their writing assignments better and also got good results. Thus, the researcher suggested that the lecturer and the students to apply a brainstorming strategy in ordered that the students' writing skills could be improved.
\end{abstract}

Keywords: Brainstorming Strategy, Teaching Writing, Writing Skills, Second-semester Students

\section{INTRODUCTION}

Writing is an essential skill for students because, from writing, students can express their feelings, ideas, or make a task. "Writing is an extremely versatile tool that can be used to accomplish a variety of goals" (Graham, Gillespie, \& McKeown, 2013). Writing is a process of producing and recording words in a form that can be read and understood by the reader. The development of academic writing skills is widely recognized as a significant educational concern, particularly at the university level (Staples, Egbert, Biber, \& Gray, 2016). Therefore, many students must concern about writing because, in the last study, they must write a thesis. "As students progress through their college years, they are asked to move from more general academic writing tasks to more specialized, discipline-specific writing (Staples et al., 2016). It can be said that writing is vital for students, especially at the university level.

Brainstorming means the use of the brain to active problem solving, and the brainstorming session aims to develop creative solutions to problems (Al-khatib, 2012). Using brainstorming makes students quickly develop the topic and solve some problems. With this method, the students will be more active in learning. It also helps the students to improve their creativity in writing, especially in organizing their ideas.

From the explanation above, the researcher assumed that using brainstorming had many advantages for students. The first, it could make students more active in class. The second, the students could develop the topics, and the last, the students could generate their ideas widely.

Therefore, the purposes of this research were to find out the implementation of the teacher's brainstorming strategy on teaching writing in second-semester students and to find out the students' responses toward the teacher's brainstorming strategy on writing a short story. 


\section{LITERATURE REVIEW}

There are some definitions of brainstorming. According to (Al-khatib, 2012), brainstorming was developed by Alex Osborn to produce ideas without inhibition. Alex Osborn, an advertising executive, is generally credited with developing modern organizational brainstorming procedures in the 1940s and 1950s (Wilson, 2013b). Brainstorming involves oral and pre-writing exercises for helping the students and for expressing ideas by the teacher. Brainstorming is an innovative discussion with unique nature in order to produce a list of ideas that can be used as clues lead students to the development of the problem while giving each student the possibility to express her ideas and share those ideas with others and encourage new ideas (Wilson, 2013a). Brainstorming is a quick way to generate a lot of ideas on a subject (Arivanianthan, 2015). The purpose of the statement is to stimulate the brain and imagine the ideas as possible. Brainstorming means the use of the brain to the actual problem solving and the brainstorming session purposes to develop creative solutions to problems (Gultom \& Gurning, n.d.). So, brainstorming is a way to develop the topic, to express ideas, to generate a lot of ideas, and to develop creative solutions, also the activity that is useful for them to start or generalize a new idea. Brainstorming has great importance in the teaching process. Referred to its importance for students in (Al-khatib, 2012) as follows:

- It helps students to solve the problems, an innovative and creative solution.

- It helps students to give advantage from the ideas of others through the development and build on them.

Writing is an extremely versatile method that can be used to achieve several objectives (Graham et al., 2013). The writing processes include the professional administration of (a) the atmosphere in writing; ( $f$ ) the limitations placed by the subject in writing; (c) the desires of the writer(s); and (d) the methods, knowledge and expertise involved in composition (Zimmerman \& Reisemberg, 1997). Based on this definition, writing is a process to reach something, to get excellent skills, and to get knowledge. We broke the writing process down into four primary domains that we label planning, prewriting, drafting, and revising and created a 7-point scoring index (0-6) to rank the different tactics in each.

1. Planning

Students collect their thoughts, gather information (from text and people), and set goals in this domain (Kolb et al., 2013)

2. Prewriting

To many college students, the idea of "prewriting" is fresh and counterintuitive to some - they wonder how writing can benefit them before their "actual" reading. Nevertheless, compositional scholars agree that this practice helps students for create, coordinate and explore new ideas (Lindeman, 2001).

3. Drafting

All participants reported completing some form of draft at least a score of one before they started the revision process.

4. Revising

All students engaged in some form of revision in our study, although their methods differed.

\section{METHODS}

Respondents

In this research, the researcher collects the data in one class in the English Department. The students were from the second semester who took Paragraph Based Writing Course. The class consisted of twenty students.

\section{Instruments}

During conducting this research, the researcher prepared and used some research instruments such as observation sheets, interview guides, and questionnaires. The observation sheet used in this research was focusing on the process of teaching and learning, which meant that the sheet would be filled when the researcher was joining the class as the observer. The contents of the observation sheet involved the activities done by the lecturer and the students during the class. The purpose of the observation sheet was to guide the researcher to get valid data on whether or not the lecturer was applying the brainstorming strategy during teaching writing. Also, the researcher wanted to find whether the students got a remarkable positive impact on the strategy applied. It could be seen from their activeness and participation during the class.

The second instruments were interview guides. There was an interview guide for the lecturer and the students at different times. The interview conducted with the lecturer was to find valid data about the application of a brainstorming strategy in the writing class. The result of this interview helped the researcher to provide a firm conclusion. The following interview guide was for the students. In this research, the researcher involved six students to be interviewed. Since it was qualitative research, the researcher stopped the process of the interview when there was no new data provided by the 
participants (students). So, it could be concluded that the sixth student gave the same data as the previous students involved in this research.

The third instrument was the questionnaire. It was provided to be filled by all twenty students of the second semester in the writing class. This questionnaire consisted of some questions about their writing skills and brainstorming strategy.

\section{Procedures}

The data collected through three methods; they were observation, interview, and questionnaire. For the observation sheet consisted of the description dealing with every step of teaching and learning activities using a brainstorming strategy. It described the open activity and close activity. In getting the data, the researcher must fill the form checking the statement toward the activities that were done by the lecturer did not do the activity mentioned in the observation sheet.

In doing the interview, the researcher used a guided interview to collect the data. The interviews were done toward the lecturer and the students. For the students, the researcher only involved six students. It was done because of the sixth student. The researcher did not get various data. So, since it was qualitative research, the researcher should stop the process of the interview because the data did not vary. For questionnaires, the researcher used a close questionnaire, which consisted of eight questions.

\section{Data Analysis}

For the data from questionnaires, the writer read and analyzed all the data that collected and then organized the data based on the students' answer. Then, for the data from the interview, the researcher listened to the students' answers again and analyzed, then lastly, transcribed all the data in the form of narrative.

\section{FINDINGS AND DISCUSSION}

As mentioned above in this research, the researcher analyzed the brainstorming strategy applied by the lecturer during teaching Paragraph Based Writing Course in the second-semester students of the English Department. According to the lecturer, this strategy was used because it helped the students solve the problem in writing since writing was not an easy lesson. When the students did not have excellent skills in writing, the result of writing would not be good, or the reader would be confused with the idea written in the story.

The lecturer said that this strategy is used to solve the problem, because the strategy employs listing and clustering, and the lecturer's remarks are similar to the theory that brainstorming is an innovative and specific discussion in order to generate a list of ideas that can help students develop the problem while giving each student the possibility (Wilson, 2013a). It meant that before students started to write, the students should look for the point first. In other words, this strategy had some steps to apply. Brainstorming it meant the use of the brain to the actual problem solving and the brainstorming session purposed to develop creative solutions to problems (Gultom \& Gurning, n.d.). It meant that the brainstorming helped students to write better as the lecturer also explained that this brainstorming strategy helped students write in English easily, such as short stories. Since every student had different skills, therefore the lecturer used this strategy in the order, the students would not be confused about what they wanted to write when they had ideas that they would write.

Brainstorming is one of the important strategies for students, because, this strategy could make students understand about the topic given by the lecturer. Therefore, the researcher was interested in observing this strategy because the researcher wanted to know that the strategy has benefits for students.

There are two objectives of the research. The first objective was to know how the lecturer implemented the strategy in the class. It means that the researcher observed the lecturer when she/he was teaching in the class. The second objective was about students' responses. It means that the researcher wanted to know that the strategy had benefits for students and made students could improve their writing.

From the result of the observation, the researcher found that the lecturer applied the strategy to make students could generate their ideas well. It can be seen that this strategy could generate students' ideas, express ideas, and produce a list of ideas. It is as explained by Arivanianthan (Arivanianthan, 2015). He said that brainstorming is a quick way to generate a lot of ideas on a subject. It means that brainstorming strategy is one of the strategies that is used for supporting students learning in class, in order that students could follow the topic easily.

From the result of the interview, it was found that most of the students said that they could receive the strategy well. In addition, they said that it could make their writing better than the previous semester because the strategy was easy to understand by the students. Furthermore, they explained that they help them in listing the ideas and in expressing their possible ideas. It is supported by (Wilson, 
2013a) who said that brainstorming is an innovative discussion with special nature in order to produce a list of ideas that can be used as clues lead students to the development of the problem while giving each student the possibility to express her ideas and share those ideas with others and encourage new ideas. The purpose of the question of interviews. The first question has purposed to get information about the steps lecturer in the learning process and in order that the researcher knows the steps more clearly how the lecturer taught the students. The second question has purposed to know about how the lecturer used the strategy were applied in the learning process because the researcher wants to know that the lecturer accurately applied the strategy. The third question has purposed to know about the lecturer problem that was faced in the learning process, based on her experience of lecturer teaching. The fourth question has been proposed to ensure that the lecturer gave students know about the strategy. The last question has purposed to know how students' responses about the strategy that the lecturer applied for them, it helpful for the students or otherwise.

From the result of the close questionnaire, it was found that most of the students said yes about the question given by the researcher. It means that the students understood the strategy applied by the lecturer. It is also assumed that most students could receive a brainstorming strategy.

From the result of the interview and questionnaire, the researcher found that the lecturer implemented the strategy well because most of the students enjoyed the learning process. From students' responses, it was found that most students like the strategy because it could make students improving themselves in writing. Besides, it helped the students to make them more effective in the learning process, especially in writing a lesson.

\section{CONCLUSION AND SUGGESTION}

Writing is one of the important skills which has to be mastered by the students because writing is an extremely versatile tool. It is supported by the theory that writing is an extremely versatile tool that can be used to accomplish a variety of goals (Graham \& Gillespie \& McKeown, 2013). In addition, the writing was not only important for students but also crucial for all people.

The writing was not only for studying but for feelings or experiences, as explained by (Graham et al., 2013) He said that writing about one's feelings and experiences can be beneficial psychologically and physiologically. So, it can be said that writing has many advantages when the students have mastered the skill.

Some strategies can be used in learning writing; one of them is brainstorming. Brainstorming is one of the strategies for motivating students in the learning process to make students improve their ideas. Besides, brainstorming is a quick way to make students improving their ideas, as stated by Arivanianthan (Arivanianthan, 2015). The theory said that brainstorming is a quick way to generate a lot of ideas on the subject.

Finally, the researcher concluded that the lecturer was successful in applying the strategy for students in the second semester. It can be proved by the students who gave many good responses when they were taught using a brainstorming strategy. It meant that the result of using a brainstorming strategy could make students improving their writing because the research focused on writing, and the students could receive the strategy.

Based on the findings, there were several suggestions in order to make some improvements for further research. First, from the students, the lecturer was success applied the strategy and made students better in writing. Second, the lecturer should try this strategy to apply in their class to introduce to the students' new strategy and make students writing better. Third, for future researchers, this research should be as comparison and reference. Then, the future researcher could develop the strategy with their creativity and good ideas, such as adding a sum of numbers for interview and questionnaire.

\section{REFERENCES}

Al-khatib, B. A. (2012). The Effect of Using Brainstorming Strategy in Developing Creative ProblemSolving Skills among Female Students at Princess Alia University College Department of Psychology and Special Education. American International Journal of Contemporary Research, 2(10), 29-38.

Arivanianthan, M. (2015). Brainstorming. UNICEF. Retrieved from https://www.unicef.org/knowledgeexchange/files/Brainstorming_production.pdf

Graham, S., Gillespie, A., \& McKeown, D. (2013). Writing: Importance, development, and instruction. Reading and Writing, 26(1), 1-15. https://doi.org/10.1007/s11145-012-9395-2

Gultom, E., \& Gurning, B. (n.d.). The Effect of Brainstorming Teaching Technique on Students ' Achievement in Writing, 1-15. 
Elia Puspitasari \& Titik Lina Widyaningsih

Staples, S., Egbert, J., Biber, D., \& Gray, B. (2016). Academic Writing Development at the University Level: Phrasal and Clausal Complexity Across Level of Study, Discipline, and Genre. Written Communication, 33(2), 149-183. https://doi.org/10.1177/0741088316631527

Wilson, C. (2013a). Brainstorming. Brainstorming and Beyond, 1-41. https://doi.org/10.1016/B978-0-12407157-5.00001-4

Wilson, C. (2013b). Chapter 1 - Brainstorming. In Brainstorming and Beyond (pp. 1-41). https://doi.org/ http://dx.doi.org/10.1016/B978-0-12-407157-5.00001-4 